\title{
ALICE NO ESPELHO: O RECURSO AO FANTÁSTICO NA FORMAÇÃO DE LEITORES JUVENIS
}

\section{ALICE NO ESPELHO: THE RECOURSE TO THE FANTASTIC GENRE IN THE DEVELOPMENT OF YOUNG READERS}

\author{
Alessandra Oliveira dos Santos Beltramim \\ Mírian Hisae Yaegashi Zappone ${ }^{2}$
}

\begin{abstract}
Resumo: O presente artigo apresenta uma leitura da obra Alice no espelho, de Laura Bergallo, publicada em 2005, integrando a Coleçáo Muriqui da editora SM. A partir da análise fundamentada nos referenciais da Literatura Fantástica, verifica-se que, no contexto da produçấo literária endereçada ao público juvenil, esta obra literária consegue superar as possíveis pretensóes didatizantes e moralizantes da coleçăo e se reveste de valor e qualidade ao recorrer aos fundamentos do fantástico como estratégia para a problematizaçăo desse tema de forte apelo didático e mercadológico como é a anorexia. A autorreferencialidade, presente na remissăo explícita à obra de Lewis Carrol, a criaçáo de um ambiente paralelo e o recurso ao duplo e à hesitaçăo se configuram como estratégias a partir das quais se viabiliza a discussáo de um tema complexo e problemático, no meio juvenil, de modo leve, mas nem por isso, menos profundo.
\end{abstract}

Palavras-chave: Literatura Juvenil. Literatura fantástic. Alice no espelho.

Abstract: This paper presentes a reading of the juvenile narrative Alice no espelho, by Laura Bergallo, published in 2005 and that is part of SM editora's Muriqui Collection. From the reading of theories about Fantastic Literature, in this study, it can be observed that this juvenile narrative, in this perspective, is able to overcome the teaching and moralizing pretensions of the Muriqui Collection and is of great value and quality, because it resorts to Fantastic genre as strategy to problematize a subject of strong educational and moralizing appeal such as anorexia. The self reference present in the explicit reference to the literary work of Lewis Carrol, the creation of a parallel environment, the recourse to double and hesitation are configured as a strategy from which the discussion od a complex and problematic matter is enabled, amonst the youth, arguing lightly, but not less profoundly.

Keywords: Juvenile Literature. Fantastic Literature. Alice no espelho.

1 Doutoranda da Universidade Estadual de Maringá e professora do Quadro Próprio do Magistério do Paraná (QPM) e atua nas áreas de leitura, letramento literário e literatura infantojuvenil. E-mail: alehigobeltramim@hotmail.com

2 Doutorado em Teoria e História Literária pela Universidade Estadual de Campinas (2001) e professora adjunta da Universidade Estadual de Maringá...E-mail: mirianzappone@gmail.com 


\section{CONSIDERAÇÕES INICIAIS}

Na contemporaneidade, no contexto da sociedade capitalista, vivemos em tempos de crise, diriam os apocalípticos ${ }^{3}$. Ao tratar da questâo da identidade no mundo contemporâneo, Bauman (2001) explica que, nesse novo contexto, năo săo apenas os valores, os sistemas, as estruturas, as convençôes sociais que perdem o seu tradicional rigor, frente às imposiçôes das leis de mercado, frente à sobreposiçăo dos valores econômicos a outros valores tantos que a cultura clássica por tanto tempo cultivou. Para o autor e criador do conceito de "modernidades líquidas", um fato bastante presente no mundo contemporâneo é a fluidez das coisas e do próprio homem que, por sua vez, ao questionar suas próprias verdades, relativiza suas concepçóes de mundo, chegando a questionar-se sobre o seu próprio ser. Tal fluidez dos tempos líquidos leva o homem a construir identidades cada vez mais transitórias, flexíveis e instáveis.

A ideia de que "tudo o que é sólido desmancha no ar", concebida por Karl Marx e retomada por Berman (1986) nunca foi tâo intensa e verdadeira, de modo a configurar náo apenas novas tecnologias, novos instrumentos, novos suportes e objetos que vêm substituir os produtos anteriores, considerados obsoletos em curtos períodos de tempo, mas também, novas crenças, novas ideias, novos valores, novas maneiras de se conceber, também, os sistemas culturais e sociais e os bens simbólicos, como a literatura por exemplo.

No campo literário, constata-se que, se no mundo das epopeias, o homem ali representado vivia em um mundo que lhe possibilitava o sentimento do conhecimento da totalidade e da plena integraçăo ao seu meio; a partir da produçăo romanesca tal ideal passa a náo existir mais. No contexto da Era da Modernidade que, segundo Berman (1986), tem início ainda no século XVI, o homem já năo conta mais com os mesmos referenciais. Suas convicçóes săo questionadas, relativizam-se e ele nâo encontra mais garantia alguma em relaçăo à própria vida e ao seu futuro. Sendo assim, o herói romanesco, bem diferente do herói épico, incorpora um constante estado de tensăo e insegurança, assumindo a condiçăo do típico herói problemático.

Também a forma de narrar do romance ganha novas configuraçōes e, mais recentemente, no contexto da indústria cultural, com avanços ainda mais intensos dos meios tecnológicos e de comunicaçâo, no seio da cultura dos hipertextos, a literatura passa a se submeter com maior nitidez às leis de mercado e consolida-se uma tendência à busca de públicos cada vez mais especializados, visando à fidelizaçăo de um mercado consumidor que garanta à produçáo literária a sobrevivência dentro do sistema cultural e mercadológico.

Confirmando essa tendência, surgem mercados cada vez mais específicos para a literatura também, os quais impōem novas exigências, novas especificidades, novas representaçôes que vâo garantir a consolidaçăo, por exemplo, no campo editorial, de uma literatura direcionada exclusivamente ao público juvenil, uma literatura que, tendo se desenvolvido paralelamente à literatura infantil, vem passando, nas últimas décadas, por um processo de legitimaçăo, para o qual tem contribuído o grande número

3 Conceito usado por Umberto Eco, no texto Apocalípticos e integrados, fazendo referência aos intelectuais que negam a possibilidade de sobrevivência da arte na sociedade dominada pela indústria cultural, tais como Teodor Adorno e Horkheimer. 
de publicaçóes e pesquisas na área. Uma literatura que, apesar de estar inegavelmente atrelada aos meios de produçăo da indústria cultural, até mesmo pela garantia da sua própria sobrevivência, tem encontrado formas de garantir padrăo de qualidade que a chancela como arte.

É no campo dessa produçáo da literária juvenil que esse estudo se fundamenta, ao propor uma leitura do romance Alice no espelho, de Laura Bergallo, obra que capta perfeitamente esse espírito da "modernidade", no sentido proposto por Berman (1986). Além de ter recebido o Prêmio Jabuti, em 2007, na categoria livro juvenil, a obra foi selecionada para compor o Catálogo FNLIJ da 44th Bologna Children's Book Fair, evidenciando sua acolhida junto às instâncias chanceladoras do sistema literário brasileiro.

Apesar da referida crise de crenças, valores e ideias, apregoada pelos mais conservadores, portanto, ainda é possível vislumbrar, no contexto contemporâneo, maior maleabilidade da literatura, o que a torna capaz de responder a novas perguntas e a corresponder a diferentes horizontes de expectativas de diferentes categorias de leitores em diferentes contextos. Quando se pensa nos leitores jovens, por sua vez, constata-se que, mais ainda, esses novos leitores, imersos no contexto da sociedade capitalista contemporânea, carregam consigo as marcas da fluidez do mundo tecnológico e globalizado e compartilham, de forma ainda mais acentuada, as mesmas incertezas e sentimentos de incompletude, de fragmentaçăo, de vazio e indefiniçăo do herói romanesco, sentimentos inerentes năo só aos novos tempos, mas também à própria adolescência, fase da vida marcada por grandes transformaçóes.

Partindo do pressuposto de que Alice no espelho é uma narrativa representativa da diversidade que constitui o específico juvenil, na contemporaneidade, propóe-se uma leitura amparada em suporte teórico sobre a literatura fantástica, concebendo-a enquanto gênero literário e náo como mero qualificativo para os elementos constitutivos da história. E, a partir dessa perspectiva, aponta-se que a obra em questâo, recorrendo aos elementos do fantástico, constitui-se como valioso suporte de leitura com potencial de entreter, sim, mas, também de formar novos leitores, ao contribuir para a representaçăo do indivíduo adolescente, de suas crises de identidade e de suas incertezas frente ao caos do mundo contemporâneo.

Afinal, se em seus primórdios, o fantástico era associado apenas a narrativas que explorassem o medo, o susto, contextualizando-se em ambientes macabros, enfatizando os lances dramáticos e instaurando o ritmo acelerado de aventura. Conforme afirma Volobuef (2000), ao longo do tempo, ele foi se transformando e incorporando maior sutileza em seus expedientes narrativos. Desse modo, a moderna narrativa fantástica foi gradativamente se depurando e abandonando a sucessâo de acontecimentos emocionantes, assustadores e surpreendentes para incorporar temáticas e esferas cada vez mais complexas e mais adequadas ao contexto do século XX. Desse modo,

a narrativa fantástica tornou-se receptiva à inquietaçăo perante os avanços científicos e tecnológicos (O homem da areia, de E.T.A. Hoffmann; Frankenstein, de Mary Shelley; Os canibais, de Álvaro do Carvalhal), aos devaneios oníricos ou de faz-de-conta (Os cavalinhos de Platiplanto, de J. J. Veiga; Aurélia, de Gérard de Nerval), às angústias existenciais e psicológicas (A metamorfose, de Kafka; The fall of the house of Usher, de E. A. Poe; A terceira margem do rio, de Guimarâes Rosa), à sensaçăo de impotência frente à realidade opressiva (Casa tomada, de Júlio Cortázar; A casa do girassol vermelho, de Murilo Rubiăo). O efeito criado por 
esses textos pode, por conseguinte, cobrir um grande leque de reaçōes: incômodo, surpresa, dúvida, estranhamento, mas também encantamento e riso (VOLOBUEF, 2000, p. 109-110).

A respeito da apropriaçăo do fantástico por obras da literatura infantil e juvenil, Pierini (2011), ao analisar contos infantis, em "Mirna Pinski e o Conto fantástico para crianças", defende que, diferentemente do que muitos pais e educadores pensam,

uma criança é um ser capaz de tratar sobre todo e qualquer assunto, desde questōes consideradas verdadeiros tabus da humanidade como as relaçôes sexuais e a morte, como também conseguem perfeitamente distinguir onde fica a fronteira entre o real e o imaginário, de acordo com a experiência e o trabalho do psicólogo Bruno Bettelheim. Isso quer dizer que uma criança sabe muito bem separar o que é o enredo de uma novela ou filme das atrocidades narradas por repórteres nos telejornais o que deveria descartar muitas das questóes levantadas acerca da violência nos desenhos animados e nos jogos de videogame, e tranquilizar aqueles que veem seus filhos rirem das pancadarias ficcionais e se comoverem ou sentirem revolta diante do sofrimento das crianças nordestinas ou africanas (PIERINI, 2011, S/P).

Na perspectiva dessa nova concepçáo do fantástico, a obra de Laura Bergallo se torna capaz de, investindo na forma composicional inerente ao gênero, captar com propriedade a inquietaçăo vivida pelo homem contemporâneo ao problematizar o tema da imposiçăo de padróes de beleza e da anorexia, propiciando interessante reflexáo sobre as questôes identitárias que atravessam geraçóes e geraçóes e afetam, de forma avassaladora, os adolescentes e jovens da sociedade atual.

\section{O ESPECÍFICO JUVENIL NA LITERATURA}

A literatura juvenil, aos poucos, num período recente, vem constituindo seu próprio espaço, num processo de distinçâo da literatura infantil, sob cuja sombra ela se desenvolveu por muito tempo. Mais precisamente, nas últimas décadas, evidencia-se que o mercado editorial já identificou a existência de um público especificamente juvenil, com características bastante singulares e, por essa razăo, tem sido bastante representativo o número de produçôes que visam alcançar esse leitor específico. Muitos săo os escritores que optam por escrever para esse novo público; muitas sâo as coleçóes e séries literárias lançadas tendo em vista esse novo perfil de público; nâo é insignificante o número de editoras que criam novos selos ou reservam em seus catálogos espaços restritos para atenderem a essa demanda do mercado criada por adolescentes. Portanto,

o reconhecimento da literatura juvenil por instâncias legitimadoras diversas - social, mercado, editorial e acadêmica - permite-lhe reivindicar um lugar na sistematizaçăo dos estudos literários e parece consenso, entre grande parte de agentes que compóem o sistema de produçấo, circulaçăo e consumo da literatura para jovens, que, como matéria prima da produçăo artística contemporânea, em todas modalidades e gêneros, tais acontecimentos e emoçôes, quando recriados esteticamente, podem propiciar aos leitores o reconhecimento e a superaçăo de momentos cruciais da existência (MARTHA, 2012, p.1). 
Hoje é possível constatar, portanto, o florescimento de um processo de legitimaçăo dessa literatura juvenil que năo só se sustenta, mas também alcançou status privilegiado, graças a algumas condiçôes propícias ao seu pleno desenvolvimento no sistema literário. Entre essas condiçôes, pode-se destacar: 1) a ampliaçăo de sua produçăo, garantida por um maior número de escritores se profissionalizando e se especializando na área e gerando, consequentemente, um maior número de obras postas em circulaçâo 2) a ampliaçăo do público, graças às influências midiáticas e às políticas públicas que fazem do governo o maior comprador de livros para disponibilizá-los para a escola; 3) o desenvolvimento do mundo tecnológico que propicia melhores condiçóes de produçáo, também, para o ramo editorial, culminando num desenvolvimento dos sistemas de produçấo dos bens simbólicos; 4) a diversificaçâo das temáticas abordadas, incluindo discussóes que tradicionalmente seriam consideradas até mesmo inapropriadas para a faixa etária da adolescência.

O campo temático da literatura juvenil, realmente, tem sido cada vez mais vasto, incluindo discussóes sobre realidades cada vez mais complexas, pertinentes năo apenas ao universo juvenil, mas à existência humana como um todo. E, assim, a literatura juvenil contemporânea, portanto, é caracterizada pela diversidade - diversidade de temas, de suportes, de formas, de gêneros. Segundo Coelho (2010), inclusive, mediante tanta diversidade no contexto dessa literatura, năo é possível se afirmar que há um ideal absoluto de Literatura Infantil/ Juvenil (nem de nenhuma outra espécie literária). Para a autora, em se tratando de literatura infantil e juvenil,

será "ideal" aquela que corresponder a uma certa necessidade do tipo de leitor a que ela se destina, em consonância com a época em que ele está vivendo... Vista em conjunto, a atual produçăo de Literatura destinada a crianças e jovens, entre nós, apresenta uma crescente diversidade de opçóes temáticas e estilísticas, sintonizadas com a multiplicidade de visōes de mundo que se superpóem no emaranhado da "aldeia global" em que vivemos (COELHO, 2010, p.289).

Nessa perspectiva, entre os temas dessa literatura, é possível encontrar os mais inusitados possíveis - a morte, os conflitos familiares, as relaçōes amorosas, a sexualidade, os problemas relacionados à própria identidade juvenil. Entre os gêneros, encontramos os romances de aventura, os romances policiais, os romances de formação - Bildungsroman - contos, poesias, novelas, inclusive com apropriaçâo do fantástico por textos juvenis.

A obra Alice no espelho, por sua vez, é um exemplar representativo dessa categoria literária que se dirige ao público jovem e que se reveste de temáticas e expedientes específicos para atrair o público jovem. Escrita por Laura Bergallo e ilustrada por Edith Derdyk, a obra foi publicada em 2005, pela editora SM e faz parte da coleçăo Muriqui, que, segundo informaçōes da própria editora, disponíveis nas contracapas dos livros, tem como projeto o tratamento de questôes delicadas inerentes ao universo juvenil, tais como a separaçâo dos pais, as relaçôes de amor e amizade e outras "coisas que a gente vive" e que, por sua vez, "merecem ser pensadas com calma" e cuidado, tal como os macacos muriquis, que estăo entre as espécies ameaçadas de extinçâo no planeta.

As temáticas específicas desse romance săo a ditadura da beleza e a anorexia. Há explícito apelo pedagógico proposto pela SM editora ao idealizar a Coleçâo Muriqui, tal como evidenciam, no livro, os encartes informativos sobre a doença anorexia e o 
depoimento comovido de uma adolescente que assina como Alice, mas que, segundo nota explicativa da autora, é uma reuniâo de uma série de depoimentos verdadeiros, de adolescentes reais. No entanto, apesar desse apelo da Coleçâo, Alice no espelho se destaca pela sua constituiçăo formal, a qual possibilita uma ampliaçăo das discussóes para além da temática proposta, possibilitando a reflexăo de questôes ligadas à identidade juvenil e à existência humana, o que a universaliza como literatura de qualidade.

Um dos expedientes de que a narrativa se vale para a superaçâo das limitaçôes do didatismo é a incorporaçáo do fantástico enquanto gênero ou modalidade literária, como um modo específico de se fazer literatura, e năo apenas enquanto um elemento narrativo. A respeito dessa categorizaçăo do fantástico como gênero, Faivre (1991) salienta que, "mais do que um gênero propriamente dito, [ele] é um procedimento de escritura, um tipo de narrativa" 4 (p.15, traduçăo nossa). De qualquer forma, mais por comodidade, mantém a denominaçáo de gênero fantástico para se referir à fraçáo da literatura que, em síntese, apesar de todas as diversidades de abordagem, tem como fio condutor o jogo sobre os limites do verificável e do inverificável, definiçăo que ele considera "um fio de Ariadne fosforescente o bastante para nos guiar através da mata fechada das correntes e obras" (p.15).

O que importa é que, na perspectiva do fantástico, a narrativa se apropria da autorreferencialidade, da interdiscursividade, da intertextualidade, da ambiguidade, do duplo, do monólogo interior, abrindo espaço, com isso, para discussôes mais complexas que envolvem os conflitos identitários pertinentes ao universo do homem moderno e ao universo juvenil como um todo e nâo apenas em relaçăo a públicos afetados pela anorexia.

\section{O FANTÁSTICO EM ALICE NO ESPELHO: ENREDANDO E FORMANDO JOVENS LEITORES}

Segundo Covizzi (1978), o insólito “carrega consigo e desperta no leitor, o sentimento do inverossímil, incômodo, infame, incongruente, impossível, incrível, inaudito, inusitado, informal..." (COVIZZI, 1978, p. 26). Mobilizado por tais sentimentos que o insólito e o fantástico podem despertar em si, o leitor é capaz de mergulhar em outros tempos e espaços, iluminando diferentes aspectos da realidade em que vive, alcançando, através da arte, uma nova compreensáo de si mesmo, de seus problemas, da sua própria vida e do mundo que o cerca.

No contexto da sociedade contemporânea, a partir das representaçóes da produçăo literária romanesca, é possível verificar a existência de um sujeito profundamente problemático, marcado pelos novos valores, pelo sentimento de vazio, de fragmentaçâo, de solidâo, de angústia, enfim, de inadequaçâo frente à fluidez dos novos tempos que leva o ser humano a diversas crises de identidade. Nessa perspectiva, diante do caos que vive o homem contemporâneo e, de modo especial, o adolescente, a imersáo no universo fantástico pode se constituir como um caminho alternativo para o enfrentamento e superaçâo dessas crises.

4 As citaçōes do ensaio de Antoine Faivre aqui transcritas săo traduzidas com a colaboraçâo de Fábio Lucas Pierini. 
Complementando a ideia do imenso potencial do insólito proposto por Covizzi (1978), Matia (2017, p.30), afirma que a manifestaçăo do insólito na narrativa ilumina as várias facetas da realidade empírica e permite ao leitor uma maior sensibilidade acerca de si e da sociedade:

nâo se trata de uma sucessāo de acontecimentos surpreendentes por sisó. Anarrativa fantástica passou a tratar do real pelo irreal, por meio de assuntos inquietantes para o homem atual, tais como os conflitos sociais, os avanços tecnológicos, as angústias existenciais e identitárias, a opressăo, a burocracia, a desigualdade social, para citar alguns (MATIA, 2017, p.30).

Desse modo, compreendemos que o fantástico [e o insólito] é capaz de enredar leitores de todas as idades e, ainda, de provocar efeitos diversos em seu público, promovendo novas formas de se enxergar, assimilar e, talvez até, transformar a realidade, tal como sugere a obra Alice no espelho, de Laura Bergallo. Afinal, vale lembrar que, segundo Volobuef (2000, p.110), o fantástico tem o potencial de fazer "emergir a incerteza e o desconforto diante daquilo que era tido como familiar". Mas como é o enredo que enreda o leitor, apresenta-se, primeiramente, uma síntese da história narrada em Alice no espelho: Alice é uma garota de quinze anos que vive com a mâe e a avó, após a separaçâo dos pais. Durante toda a narrativa, evidencia-se uma enorme carência afetiva dupla na vida de Alice: a primeira, causada pela saudade do pai, com quem ela demonstra forte ligaçấo, - ao citar o tempo todo trechos das histórias que ele lhe contava -, mas que saiu de casa e nunca mais lhe deu notícias; a segunda, da própria măe que, apesar de morar junto com ela, é muito ausente e só se preocupa com o trabalho, com a sua boa forma, com dietas e com exercícios físicos.

Nesse romance juvenil, o sentimento de tristeza, a insegurança, o vazio, a solidăo de uma adolescente que se sente abandonada por todos, após o divórcio dos pais, constituem o território líquido, fluido, instável e caótico que assombra a protagonista, comprovando realmente o desmonte de tudo o que antes era sólido em sua vida, tal como propóe Berman (1986) ao retomar a célebre concepçâo de que "tudo o que é sólido desmancha no ar", de Karl Marx. Para Covizzi (1978, p. 26-27), a crise de valores que afeta o homem do século XX provoca a existência de um mundo em crise, que, por consequência, é um mundo náo-sólito, já que tanto as convençóes de realidade, quanto seus conceitos e representaçóes năo săo mais considerados absolutos e, por isso, năo sâo aceitos sem questionamentos.

A crise de identidade toma conta da menina sobre quem, na infância, "todo mundo dizia que ela era linda e magra, e era exatamente isso o que Alice pensava também" (BERGALLO, 2005, p.10). O caos se instala, porém, aos oito anos, quando, por alguma razăo desconhecida, o pai foi embora de casa. Justamente o pai que ia ao seu quarto todos os dias e lhe contava incessantemente as histórias de Alice.

Mas agora nâo tem mais nada disso. Tem a mâe, é verdade, sempre com pressa entre uma sessăo de aeróbica e outra de musculaçăo. Mas năo tem mais histórias de Alice, risadas altas, a barba crescida do pai roçando seu rosto num carinho meio áspero. Alice procura esquecer. Mas também procura lembrar. Lembrar-se do pai é ficar mais um pouco junto dele. Mas também faz Alice viver de novo aquele abandono, que náo parece muito justo com ela. O pai largou a măe, casou de novo, teve outros filhos. A mâe ficou sem marido e Alice ficou sem pai. Em algum lugar de sua história, Alice procura uma culpa que explique sua ausência. E já nâo acredita no país das maravilhas (BERGALLO, 2005, p.11-12). 
A falta de crença no país das maravilhas (espaço com o qual a obra dialoga por meio da homonímia das protagonistas), nesse caso, é associada à falta de autoestima, de esperança e de qualquer entusiasmo pela vida. Tal sentimento de inquietaçâo, de frustraçăo, tal como proposto por Volobuef (2000) instaura um terreno propício para o fantástico. De tanto presenciar a vaidade e preocupaçăo da máe com a boa forma, a menina é acometida por uma séria doença que faz com ela se sinta demasiadamente feia, gorda e insatisfeita com seu próprio corpo. E, assim, ao idealizar a beleza de modelos televisivos, ela sofre de gravíssimos distúrbios psicológicos e alimentares. Por isso, fica horas sem comer, depois devora compulsivamente um pudim inteiro ou uma caixa de bombons; depois se arrepende e, escondida no banheiro, provoca o próprio vômito. Entăo, fica muito fraca, os desmaios văo se tornando cada vez mais frequentes, inventa planos mirabolantes para enganar a máe e a avó e fingir que se alimenta, mas joga toda a comida fora. A doença atinge proporçôes altamente prejudiciais até que, um dia, após devorar um pote inteiro de sorvete em seu quarto, ela corre ao banheiro para vomitar, fica muito fraca e "năo se mexe mais" (BERGALLO, 2005, p.50).

É nesse momento que surge o recurso ao fantástico como única alternativa possível de superaçăo do problema para a menina que năo acreditava mais no país das maravilhas. A conduçáo da menina para um universo diferente, cheio de magia e marcado pelo fantástico é realizada como um recurso para o resgate da sua crença em si mesma, da recuperaçăo da sua autoestima e para a sua tomada de consciência sobre a existência de um problema que precisa ser enfrentado. A partir daí, a narrativa provoca hesitaçâo - tăo preciosa a Todorov (1975), em sua obra intitulada Introduçâo à literatura fantástica, e fonte de polêmicas discussóes entre os estudiosos do gênero (PIERINI, 2010; GAMA-KHALIL, 2013) - e ambiguidade, náo esclarecendo se os episódios que sucedem săo verdadeiros ou se săo apenas fatos imaginados, resultantes dos delírios da garota que estaria desacordada. Para Todorov (1975), nós leitores, somos transportados para o âmago do fantástico quando

num mundo que é exatamente o nosso, aquele que conhecemos, sem diabos, sílfides nem vampiros, produz-se um acontecimento que năo pode ser explicado pelas leis deste mesmo mundo familiar. Aquele que o percebe deve optar por uma das duas soluçóes possíveis; ou se trata de uma ilusâo dos sentidos, de um produto da imaginaçăo e nesse caso as leis do mundo continuam a ser o que săo; ou entăo o acontecimento realmente ocorreu, é parte integrante da realidade, mas nesse caso esta realidade é regida por leis desconhecidas para nós (1975, p. 30).

Referenciando Todorov (1975), Gama- Khalil defende que o gênero fantástico acontece exatamente em funçăo dessa incerteza, que provoca o que Todorov designa como hesitaçáo. A dúvida entre uma explicaçăo lógica e uma explicaçăo fantasiosa, sobrenatural para os fatos que se sucedem numa narrativa é essencial para a definiçáo do gênero, aliás, "essa seria, pois, a condiçăo fundamental para a existência do fantástico" (GAMA-KHALIL, 2013, p.20).

Para Todorov (1975), săo três as condiçōes básicas para a configuraçăo do fantástico na literatura: primeiramente, a narrativa deve exigir do leitor uma avaliaçăo do mundo das personagens como o seu mundo real e uma hesitaçáo entre dar uma explicaçáo natural ou uma explicaçâo sobrenatural aos fatos narrados. Uma segunda condiçăo é a de que tal hesitaçâo seja experimentada, também, por uma personagem da narrativa, 
de modo que o leitor possa nela se espelhar, mergulhando em suas vivências insólitas, como num jogo de espelhos e, por fim, uma terceira condiçấo é a de que o leitor tome uma determinada atitude em relaçấo à narrativa, devendo descartar tanto a interpretaçăo alegórica como a interpretaçăo poética (TODOROV, 1975).

O fato é que, em Alice no espelho, a empatia entre leitor e protagonista é estabelecida desde o início, quando a narrativa apresenta uma protagonista imersa em conflitos internos muito compreensíveis para o leitor adolescente. A menina que transita de uma infância feliz para uma adolescência problemática, conflituosa, marcada pelo sentimento de inadequaçăo ao seu próprio corpo e ao seu meio, quer por sua fragilidade, por sua angústia e sofrimento resultante do abandono, conquistam uma identificaçăo imediata com o leitor, que reconhece, na trama, um mundo identificado com o seu mundo real, um mundo marcado por fatos e experiências do universo adolescente, com apelo midiático pela beleza, pela magreza, pelo consumo e consumismo de cosméticos, roupas, dietas. Enfim, um mundo marcado por padrōes estéticos exagerados e por uma grande pressáo pela adequaçăo e consequente alienaçáo do sujeito. Assegura-se, assim, uma parte da primeira condiçáo proposta por Todorov: a identificaçăo do leitor entre o mundo real e o mundo das personagens. Já na epígrafe inicial, retirada da obra de Lewis Carrol, há um convite para que se acolha "o convite de um conto de fadas" (BERGALLO, 2005, p.10), para que de fato, o leitor seja introduzido no universo referencial da trama e com ele se identifique, hesitando sobre o que vê, oscilando sua interpretaçăo entre realidade e fantasia: "Criança da fronte pura e límpida / E olhos sonhadores de pasmo! / Por mais que o tempo voe e ainda / Que meia vida nos separe, / Irás por certo acolher encantada / O presente de um conto de fadas" (BERGALLO, 2005, p.10).

A segunda parte da primeira condiçăo, a hesitaçăo, ocorre quando, após um suposto desmaio, a menina se levanta do châo e fica diante do espelho de seu próprio quarto, onde vê uma garota muito gorda olhando para ela, dentro de um quarto semelhante ao seu, mas em posiçăo invertida. A menina "gordona" e o quarto invertido do espelho pode ser o duplo, a imagem duplicada de Alice e de seu próprio quarto refletido, até porque, por sofrer de anorexia, Alice sempre se enxerga mais gorda do que realmente é.

No entanto, num jogo de faz-de-conta que aprendera com as leituras que fazia do livro Alice através dos espelhos, com o seu pai, numa evidente referência a Alice no país das maravilhas, de Lewis Carrol, Alice toca o espelho e ele amolece, de modo que ela consegue penetrá-lo para presenciar, do outro lado, numa espécie de mundo paralelo:

Atrás dela, um quarto igualzinho, só que com tudo em posiçăo invertida. E resolve fazer de conta, como a outra Alice (a do país das maravilhas), que o espelho de repente ficou todo macio e que é possível atravessar para o outro lado.

Encosta a ponta dos dedos no vidro (e a garota gorda faz a mesma coisa). A superfície lisa começa a amolecer e vai se dissolvendo devagar. $O$ espelho se transforma numa tênue nuvem de prata e, no instante seguinte, vemos Alice do lado de lá (BERGALLO, 2005, p. 52, grifo nosso).

Devido ao desmaio de Alice, a hesitaçăo do leitor e a ambiguidade săo explícitas: é possível que tudo seja apenas um delírio e que os fatos năo sejam reais, sejam meros frutos da imaginaçăo da menina. Mas o narrador também compartilha dessa visăo de Alice, invadindo o outro lado do espelho, náo só nesse momento em que o fato inusitado 
ocorre, mas durante toda a narrativa: "Mas se chegarmos perto, veremos exatamente a mesma cena. Uma coisa muito estranha, muito improvável, mas bem real: Tiago e Mirna Lee trocando um beijo daqueles!" (BERGALLO, 2005, p.55).

Para garantir a segunda condiçăo de existência do fantástico, em alguns momentos, até o narrador hesita sobre a veracidade do que vê: "E acaba ficando mais embaralhado ainda. Porque, bem perto delas, sem ligar para a cena romântica do casal de namorados, passa outra pessoa que năo podia estar ali. Um gêmeo de Tiago! Ou será um clone?" (BERGALLO, 2005, p.58).

Nesse universo paralelo, uma série de fatos contribui para que Alice organize suas ideias e vá tomando consciência do problema que a atinge no mundo real. A travessia do espelho é, portanto, o elemento absurdo desencadeador de toda a trama; ela torna possíveis coisas consideradas impossíveis, permite visibilidade ao que é invisível, torna experienciável o que nâo seria possível experimentar num mundo restrito ao plano da lógica e da razâo. A partir daí, a história se passa muito mais no plano da imaginaçấo de Alice, na mente da protagonista do que no plano da realidade, das açóes, dos eventos propriamente ditos, dando forma a mais uma característica do fantástico como gênero.

A hesitaçâo se faz presente para o leitor que nâo tem certeza sobre uma explicaçâo lógica e coerente para os fatos, mas tal sentimento năo é exclusividade dele, visto que, em muitos momentos, ele é estimulado pela hesitaçăo do próprio narrador, garantindo-se o cumprimento da primeira e segunda condiçóes para a caracterizaçấo do fantástico estabelecida por Todorov: “E claro que Alice, como aliás todos nós, está muito curiosa para resolver o mistério. Que lugar estranho esse mundo do espelho! Umas vezes parece sonho, em outras dá para jurar que é tudo verdade" (BERGALLO, 2005, p.58, grifo nosso).

E, mesmo no mundo paralelo, a cabeça de Alice fervilha diante dos dilemas que atormentam sua existência, sendo comum o recurso ao monólogo interior em que ela relembra citaçóes da obra original de Alice no país das maravilhas, contada por seu pai em sua infância; revive seus conflitos, sua vontade de ser magra e linda, ao mesmo tempo em que sente uma fome absurda, mas năo quer nem pensar em comida e contempla tudo o que acontece de mágico e absurdo à sua volta.

Sem dúvida, a possibilidade de atravessar um espelho, visitar um mundo paralelo, viver aventuras nesse mundo e voltar para o tempo e espaço em que estava antes de partir, parece realmente absurdo e ininteligível para a consciência do leitor do texto. No entanto, tais acontecimentos năo săo tăo absurdos assim e passam a ser até mesmo explicáveis no universo da literatura. Como característica constante da literatura fantástica, a autorreferencialidade se faz presente durante toda a narrativa de Alice no espelho e ajuda a explicar e/ou, no mínimo, a tornarem verossímeis os fenômenos absurdos, que causam inquietaçăo e estranhamento nos leitores. Numa clara referência intertextual ao clássico de Carrol, a narrativa é, do começo ao fim, intercalada por citaçôes diversas das histórias contadas pelo pai de Alice quando criança. Através desse diálogo intertextual, a narrativa justifica os rumos que ela toma, explica os fenômenos mais absurdos, fazendo referência a si mesma, com a nítida pretensăo de persuadir o leitor a comprar a ideia de que a história que lê é plausível ou, no mínimo, verossímil, no plano da ficçăo.

A autorreferencialidade é uma característica fundamental do gênero, contribuindo 
para a consolidaçăo de uma tradiçăo da literatura fantástica. Por isso, as aventuras de Alice no mundo paralelo apresentam vários elementos que reforçam o mistério e a hesitaçâo, com a inclusâo de cenas estranhas, absurdas, mas muito coerentes com o tema adotado pelo livro e com o gênero da literatura fantástica. Nessas cenas, a própria Alice e todo o seu mundo é duplicado. Ela vê seu próprio mundo e a si mesma em reverso. Lá, ela faz amizade com Ecila que, além de ser um anagrama de Alice, é o seu oposto completo, pois é uma menina muito gorda e nada preocupada com a aparência, travando sérias lutas contra seus familiares e o seu grupo social por nâo aceitar se submeter a um processo de transformaçáo mágica que lhe asseguraria a beleza e a eterna juventude.

Ecila, muito convicta de seus princípios e valores, năo abre mâo de ser exatamente como é, năo quer se adequar ao padrăo social, năo quer se anular através de um tipo de procedimento cirúrgico específico que a transformaria em quem ela "quisesse" ser. Por isso, ela foge desesperadamente de seus familiares o máximo que pode para que náo seja obrigada a escolher um exemplar de modelo famosa no qual se transformar. E é somente quando é pega à força por seus tios que ela se submete ao tal procedimento, cumprindo um rito pelo qual todos os seus familiares passaram.

O duplo faz uma remissâo à disputa de espaços e de lugar em uma sociedade em que é praticamente impossível se diferenciar dos demais. Sentir-se duplicado, à primeira vista, pode ser algo positivo, mas com o tempo se torna uma angústia, um motivo de preocupaçăo que inquieta a personagem (FREUD, 2010).

Alice, tăo vaidosa e tăo preocupada com a aparência, năo consegue compreender que Ecila năo queira se transformar em uma linda modelo, até porque o maior pesadelo da amiga é justamente o seu maior sonho. Quando vê outras pessoas que se submeteram à transformaçăo e se tornaram lindas, Alice entra num verdadeiro estado de contemplaçâo muito semelhante ao vivenciado por Natanael, do conto "O homem da areia", de E.T.A. Hofman (2010) diante da boneca Olympia. Mesmo usando um binóculo, Natanael náo consegue enxergar nitidamente a boneca e vê até os olhos úmidos de sua amada. Ao invés de ajudar a enxergar melhor a realidade, o binóculo diante do olhar subjetivado do observador Natanael a distorce. De modo semelhante, Alice fica vislumbrada diante dos clones de tantas celebridades que ela admira e quer imitar que enxerga a realidade distorcida, pois sua visâo é subjetivada por sua vaidade, por seu interesse em ser magra, pela sua visáo idealizada das atrizes e modelos que ela conhece da televisâo. O estado de contemplaçăo em que Alice se coloca modifica seu estado de consciência, promovendo o inquietante freudiano, impedindo-a de enxergar as coisas como realmente sâo, com precisăo de detalhes.

Ao ver a amiga Ecila transformada em mais uma cópia - entre tantas outras - da modelo Mirna Lee, de quem ela é fă, portanto, Alice insere em novo estado de contemplaçăo, mas que dura pouco, pois, pela primeira vez, ela parece despertar de seu estado de alienaçăo: "As médicas começam a retirar as faixas, começando pelos pés. Belas e longas pernas vâo aparecendo devagar, e Alice engole em seco. Aquela năo parece Ecila!" (BERGALLO, 2005, p.135).

A admiraçấo pela beleza da amiga passa a se confundir com uma angústia, com um incômodo que a inquieta e o que antes a seduzia passa a ser visto como algo "de difícil digestăo", já que a protagonista "engole em seco". Alice desconhece a pessoa que 
aparece debaixo das faixas: "Para Alice, definitivamente, nâo é Ecila. Uma avassaladora saudade da amiga oprime seu peito enquanto um silêncio cheio de expectativa continua a acompanhar o trabalho cuidadoso da médica" (BERGALLO, 2005, p.135-136). Ela reconhece a beleza do modelo "de clone" escolhido, até admite, para si mesma que escolheria o mesmo exemplar, "mas náo consegue comemorar com os outros" (idem, p.136), sendo libertada de seu antigo estado de deslumbramento.

A partir desse momento, Alice assume o comportamento de Ecila antes da cirurgia e é ela, agora, quem presencia todo o sofrimento da amiga e se compadece de sua dor, pois aprendera a gostar dela do jeito que ela era. Após o procedimento, quando Ecila acorda transformada na modelo preferida de Alice, ela náo consegue disfarçar os sentimentos ambíguos de alegria e admiraçăo pela beleza da amiga, mas de tristeza e decepçấo por perceber que Ecila mudara radicalmente seu jeito de ser, sentindo-se muito confortável na nova posiçấo. Alice começa a pensar sobre o que faz uma pessoa ser quem realmente é e, entăo, percebe que aquela năo era mais sua amiga Ecila, de quem aprendera a gostar tanto e sente falta da identidade da amiga. Inclusive, Alice decide partir do universo paralelo, mas antes, cumpre uma promessa feita a Ecila antes da tal transformaçăo, insistindo que a amiga releia o livro Alice no país das maravilhas. Tal livro foi o responsável pela opçáo de vida do pai de Ecila, que vive exilado em um lugar distante por ter sido considerado louco ao se recusar se submeter à transformaçấo.

O pai de Ecila é visto socialmente, naquele universo paralelo, como um verdadeiro monstro, um sujeito velho, doente, em estado de decrepitude. A fala de uma tia de Ecila revelam bem a concepçăo que aquela sociedade tem da velhice:

\footnotetext{
- Ficar velho é vergonhoso, é indigno [...]. Aquela cara enrugada, o cabelo ralo e branco... - sua expressáo é de desprezo e asco. - E ser feio é uma aberraçăo. Quem năo pensa assim é anormal, está doente e representa uma desonra horrível para a própria família. Infelizmente, como meu pobre irmáo caçula (BERGALLO, 2005, p.78).
}

Deixando sua amiga entretida na leitura do livro prometido, Alice parte de volta para seu ambiente original; atravessa o espelho e deixa o final da história de Ecila em aberto, para que o leitor possa imaginar e construir seu próprio final. Ao leitor năo é dado a conhecer se Ecila se afetará diante da leitura do livro, se ela resgatará sua verdadeira identidade, travando novas lutas contra sua gente e defendendo seu próprio pai, que vive excluído, ou se abrirá măo de vez de suas antigas convicçôes, se vai mesmo se afastar de seu próprio pai (conforme lhe exigiam as convençóes sociais), permanecendo acomodada ao gosto coletivo, alienada com o corpo novo que ganhara após o procedimento cirúrgico.

Após atravessar o espelho de volta, Alice encontra-se desmaiada no tapete de seu quarto, exatamente onde estava antes de atravessar o espelho. Após ter sido socorrida por seus familiares, é levada para um hospital e fica uma semana no CTI entubada, cercada de aparelhos. Lá, ela recebe a visita do pai, que afirma ter sido proibido pela máe de visitá-la e promete nâo mais abandoná-la. Ao sair do CTI, Alice admite a uma amiga, pela primeira vez, a necessidade de ajuda para deixar de sentir raiva do seu próprio corpo. Ela reconhece que precisa de tratamento, o que é um primeiro e significativo passo para sua recuperaçăo. Vendo, na televisăo, o anúncio de um milagroso programa de emagrecimento, ela percebe que seu mundo é muito mais parecido com o universo 
paralelo do que ela própria imaginava. A própria protagonista, portanto, realiza a comparaçáo para o leitor entre o mudo real, supostamente compartilhado por ambos, pelas semelhanças entre eles, e o universo paralelo que ela visitou.

Alice também ganha consciência de que os valores que lhe causaram estranhamento e que, no ambiente paralelo, eram considerados absurdos por sua amiga Ecila, eram aceitos sem contestaçăo no mundo real. Afinal, no mundo real, onde a ditadura da beleza e da magreza imperam, a velhice também é concebida como algo monstruoso, uma fase a ser adiada, evitada, disfarçada o tempo todo; os procedimentos estéticos săo cada vez mais bem aceitos e as pessoas sâo cada vez mais valorizadas por aquilo que elas aparentam, em prejuízo de sua essência humana.

\section{CONSIDERAÇÕES FINAIS}

O mundo duplicado em reverso, onde boa parte da história se ambienta, na verdade, é uma cópia estranha do mundo real, que, de um modo ou de outro, acaba refletindo os mesmos valores, crenças, concepçôes e dilemas pertinentes à humanidade.

Desse modo, o apelo ao fantástico, na narrativa, se configura como o caminho por meio do qual a protagonista pode interpretar seu próprio mundo, sua própria história, de modo a ganhar consciência dos problemas e dos conflitos que afetam sua identidade. Nesse processo, a protagonista e o próprio leitor se tornam capazes de questionar a realidade que vivenciam; instaura-se a incerteza, questiona-se aquilo que era tido como familiar. Assim, o desconforto provocado por tal experiência pode funcionar como um efeito consideravelmente positivo em ambos, ajudando-os (personagens e leitores) a compreender sua própria condiçấo frente à força avassaladora da realidade, muitas vezes bastante cruel para o ser humano.

Assim, a narrativa se configura como uma metáfora năo só dos dilemas tâo comuns à adolescência, destinatário específico da obra de literatura juvenil, mas também de alguns conflitos vivenciados por outros grupos etários frente aos padróes estéticos dominantes no mundo contemporâneo.

A narrativa Alice no espelho, portanto, configura-se como material de leitura propício a contribuir para a formaçăo de novos leitores, dentro desse espaço novo de criaçăo que se constitui em torno da produçâo literária juvenil. Afinal, apesar de sua estreita relaçấo com o mercado e com a indústria cultural e, inclusive, do apelo didatizante da coleçâo Muriqui, como se nota em outros de seus títulos, a obra se reveste de originalidade que se legitima por meio do gênero fantástico, do recurso ao absurdo, do tratamento lúdico dado ao tema, do caráter universal que a narrativa assume ao trazer à tona discussóes relacionadas aos dilemas humanos enfrentados por diferentes geraçōes. 


\section{REFERÊNCIAS}

BAUMAN, Z. Modernidade líquida. Rio de Janeiro: Zahar, 2001.

BERGALLO, L. Alice no espelho. Sáo Paulo: Ediçōes SM, 2005. - (Muriqui)

BERMAN, M. Tudo o que é sólido desmancha no ar:a aventura da modernidade. Sáo Paulo: Companhia das Letras, 1986.

COELHO, N. N. Panorama Histórico da Literatura Infantil/Juvenil: das origens indo-europeias ao Brasil contemporâneo. 5 ed. - Barueri, SP: Manole, 2010.

COVIZZI, L. M. O Insólito em Guimarâes Rosa e Borges. Săo Paulo: Ática, 1978.

FAIVRE, A. Gènese d'un genre narratif, le fantastique (essai de périodisation) - Gênese de um gênero narrativo, o fantástico (ensaio de periodizaçáo). In: Colloque de Cerisy - La litterature fantastique, Albin Michel, Paris, 1991, pp. 15 a 41.

FREUD, S. O inquietante. In: Obras Completas. Vol. 14. Săo Paulo: Companhia das Letras, p. 329-376, 2010 (Coleçăo Novelas Imortais).

GAMA-KHALIL, M. M. A literatura fantástica: gênero ou modo?. Terra roxa e outras terras - Revista de Estudos Literários. v.26, n 1-130, p.18-31, 2013). Disponível em: <http:// www.uel.br/pos/letras/terraroxa/g_pdf/vol26/TR26b.pdf>. Acesso em: 08 nov. 2017.

HOFFMANN, ETA. O homem da areia. In: SABINO, Fernando (Org). O homem da areia. 1. ed. Sáo Paulo: Rocco, 2010.

MATIA, K. C. A Narrativa Juvenil Brasileira: Entre Temas e Formas, O Fantástico, 182 f. Tese (Doutorado em Letras - Estudos literários): Universidade Estadual de Maringá, Maringá, 2017.

MARTHA, A. A. P. Anos de chumbo na perspectiva da narrativa juvenil contemporânea: Ordem, sem lugar, sem rir, sem falar, de Leusa Araujo. In: $2^{\circ}$ CIELLI: Colóquio Internacional de Estudos Linguísticos e Literários , 2012, Maringá: Anais Eletrônicos. Maringá: UEM (Estudos Literários). Disponível em: 〈http://anais2012.cielli.com.br/ pdf trabalhos/819 arq_1.pdf>. Acesso em: 20 jul. 2013.

PIERINI, F. L. Mirna Pinski e o Conto fantástico. 2011. Disponível em: $<$ https://nuhtaradahab.wordpress.com/2011/10/08/fabio-lucas-pierini-mirna-pinsky-e-o-conto-fantastico-para-criancas/>. Acesso em: 03 mar. 2018.

PIERINI, F. L. Sexto sentido, Corpo fechado e Sinais - filmes dentro das teorias literárias. Revista JIOP, $\mathrm{n}^{0} 1$ - Maringá: Departamento de Letras da UEM, 2010. Disponível em: <http://www.dle.uem.br/revista jiop_1/artigos/pierini.pdf >. Acesso: 08 nov. 2017. 
TODOROV, T. Introduçâo à literatura fantástica. Săo Paulo: Perspectiva, 1975.

VOLOBUEF, K.. Uma Leitura do Fantástico: a invençăo de Morel (A. B. Casares) e O processo (F. Kafka). Revista Letras, Curitiba, n. 53, p.109-123, jun. 2000. Disponível em: 〈http://revistas.ufpr.br/letras/article/view/18866〉. Acesso: 08 fev. 2018.

Submetido em 20 de março de 2018

Aceito em 17 de maio de 2018 